\title{
Cultural citizenship and labor rights for Oregon farmworkers: The case of Pineros y Campesinos Unidos del Nordoeste (PCUN)
}

Stephen, Lynn

This article uses the story of Oregon's only farmworker union, Pineros y Campesinos Unidos del Noroeste (PCUN), and worker testimonies to illustrate how cultural citizenship has been created for some farmworkers through grassroots organizing around immigration, cultural, and labor issues. The notion of "cultural citizenship" offers anthropologists a model for understanding how Mexican migrants in the U.S. can be recognized as legitimate political subjects claiming rights for themselves and their children based on their economic and cultural contributions regardless of their official legal status. Cultural citizenship is an alternative concept to "legal citizenship," which labels undocumented migrants in the U.S. as "illegal aliens," and is a way of reaffirming the contributions of Mexican migrants outside the framework of U.S. immigration law. Key words: labor rights, cultural citizenship, farmworkers, Mexican immigrants, Oregon It is late October and the harvest season is over for the year in the Willamette Valley in Oregon. The afternoon sun is low, and outside several units of manufactured housing stuffed with bunkbeds and clothes about 15 men are hanging around. Some work on the engine of a 1989 Dodge van that will soon make the trip back to the small village they came from in Michoacan, Mexico. Four men shoot hoops at a basketball net suspended in the middle of a concrete patio next to some hothouses for produce, their only audience a line of three blue portajohns. Others smoke and talk. The rainy season has begun and the area is starting to turn to mud. Off to one side a gray-haired man in tennis shoes, brown pants, and a button-down shirt open at the top sits on an old tire and looks at the sinking sun, slowly blowing smoke out in curls through his mouth.

I came to this labor camp with my students and Leonides Avila (not a pseudonym), a Mixtec organizer and farmworker who worked for Oregon's only farmworker union, PCUN, or Pineros y Campesinos Unidos del Noroeste (Northwest Treeplanters and Farmworkers United). My students and I have been working with PCUN since 1998 to document the history of Mexican immigration and farmworker organizing in Oregon, to highlight the experiences of Mexican farmworkers in the state, and to create tools for public education around farmworker labor rights and housing conditions, the economic and cultural contributions of Mexican immigrant workers, and racism against 
farmworkers. The research has been driven by a model I call collaborative, activist ethnography, which I discuss below.

The older man sitting on the tire was Don Francisco.' We begin to talk as the air got cooler and the sun drooped ever lower. He first came to the United States as a part of the Bracero Program (1942-1964),2 often working more than one contract per year.

Lynn: When did you first come here?

Francisco: I first came here in 1958. 1 was contracted 12 times under the Bracero

Program. I was 18 years old when I first came. In 1958, they only paid us 75 cents per hour.... I worked in Texas, California, and Arizona as a Bracero.

Lynn: Did you stop coming when the Bracero Program ended?

Francisco: Well, I stopped coming for three or four years, but then I came as what they called a mojado (undocumented). 3 I went back to work in Texas, Arizona, and California where I was contracted before.

Lynn: When did the other men (referring to those hanging around) begin to come here? How many came?

Francisco: Well, at first only three or four came, then a few more. These men returned and brought others and now there are about 40 to 50 people who come to this camp.... Right now there are about 15 people here from my community. Two of them have papers (are legal).

Lynn: Do you know when they started to come here?

Francisco (shouting to others): Hey, when did you all first come here?

One man shouting: Twenty years ago.

Another: I came about 15 years ago.

Francisco: You can see, some have been coming a long time. Most of those here from my town began to come here about 15 years ago. Some of them worked in California before they came here.... You know that it isn't easy to come here. The migra (Immigration and Naturalization Service) is really tough, especially in Texas. They have grabbed us a lot of times there. That Border Patrol is really hard to get by.... You know, why is the border so closely guarded to your country? We are the neighbors of this country. We are your neighbors....

Lynn: How do you think the U.S. government should deal with the border and people who want to come here?

Francisco: Well, I wanted to bring my children here. I wanted to bring them here but the government didn't want to give the papers for my children. They didn't want to give me 
the certificates to let me bring them legally. No. This country is very rigid.... They want us to work, but not to stay and bring our families and live here.

Around us, the men were relaxing after a long day in the fields. Some had been harvesting the last pumpkins of the season, others making a final cut of cauliflower as they work stooped behind a tractor pulling a large wagon the stalks are tossed in. They are just two dozen of about 100,000 workers who labor in Oregon agriculture-98 percent of these laborers are Latino, primarily of Mexican origin.4 Many of these farmworkers live permanently in the state; others move on.5 Such is the case of the men in this camp. While farmworkers are key to Oregon's agricultural production, they do not enjoy many of the basic protections provided for other workers. Federal laws that govern wages and hours, overtime, and many benefits do not apply to farmworkers, and states can create their own statutes for farmworkers. For example, while Oregon farmworkers can now join a labor union, growers are not required to recognize it. Until 1990, farmworkers were prohibited from even picketing during a harvest. Farmworker housing is often substandard and farmworkers may be overcharged for housing, food, and transportation by labor contractors, ending up with very little in their paychecks. In sum, farmworkers are treated as a second-class group who do not deserve the same rights and protections awarded to other workers. These conditions and the experience of farmworkers in different parts of the United States have been amply documented by social scientists. (See Rothenberg 2000:329-332 for an excellent list of historical and current sources describing the farmworker condition in the U.S.)

Francisco's discussion highlights how immigration from his hometown in central Michoacan to the Willamette Valley in Oregon has been linked to U.S. immigration policy. "Legal" immigration through the Bracero Program generated well-rooted networks that expanded after the program ended. This same phenomenon was repeated in 1986 when the United States granted legal residency to 2.8 million immigrants through the 1986 Immigration Reform and Control Act CIRCA) and over 1 million undocumented farmworkers were legalized through the Special Agricultural Worker (SAW) program (Rothenberg 2000:141). Once legalized, their undocumented relatives often joined them. The Immigration and Naturalization Service (INS) and the Urban Institute estimated that by the mid-to-late 1990s the number of undocumented workers in the United States was between 6 and 9 million, and that they were entering at a rate of 200,000 to 300,000 per year (Waslin 2001:36).

The climate of the United States following the events of September 11, 2001, widened 
the political space for antiimmigrant sentiments considerably, building on the negative historical legacy of the ways "illegal aliens" have been constructed in this country. Now more than ever, immigrant workers such as Don Fransisco are searching for recognition of their long-term contributions to the U.S. economy and society and for the right to work and live in the United States. They are struggling to become a recognized and valued part of the communities where they live and work.

Cultural Citizenship and Mexican Immigrant Workers in Oregon

On that day in October, our research agenda was to document some of the variable housing conditions of farmworkers in different labor camps. We also received an unexpected lesson on the causes of immigration and the reasons Mexican immigrant workers feel they deserve recognition for their economic, cultural, and political contributions to the United States. William V. Flores and Rina Benmayor (1997) have put forward the notion of "cultural citizenship," which offers a model for understanding how Mexican migrants in the U.S. can be recognized as legitimate political subjects claiming rights for themselves and their children based on their economic and cultural contributions, regardless of their official legal status. In other words, the kinds of civil rights, respect, and recognition granted to legal U.S. citizens can be extended to all residents who contribute to U.S. society. The notion of cultural citizenship is an alternative concept to "legal citizenship," which labels undocumented migrants in the U.S. as "illegal aliens." It reaffirms the contributions of Mexican migrants outside the framework of U.S. immigration law and within the framework of transnational communities.

The legal labeling system that includes the terms "citizen," "resident alien," and "illegal alien" is historically wedded in Oregon to a racial hierarchy codified in the original state constitution of 1853, which glossed "Mexicans" as "Indians" and denied them the right to own land and vote. A century later, Mexican workers were called "wetbacks" and "illegals" and were detained and deported after the state withdrew from the Bracero Program in 1947, after only three years of participation. Raids and deportations continued until the late 1990s. The second-class status of Mexican immigrants as workers is reinforced by the racial history of the western U.S., which has continually defined people of Mexican descent as racially inferior, biologically suited for agricultural labor, culturally traditional and backwards, and in need of supervision and programs of assimilation into "American" society (see Foley 1997; Garcia 2001; Gutierrez 1995; Menchaca 2001). Because of this racial history, any organizing efforts by Mexican 
immigrants-whatever their legal status and whatever the focus of the organizing activityis read against a cultural script that renders them outsiders.

The positive proposition of cultural citizenship provides an opening for Mexican immigrant workers to belong-as citizens-in the communities they live in. It also positively affirms recognition, respect, and celebration of cultural differences associated with processes of border-crossing and migration. Some recent work (see Appadurai 1996; Hardt and Negri 2000) suggests that global capitalist processes, universal neoliberal economic principles and policies, and the hegemony of North American popular culture may increase cultural and economic homogenization on a global scale. The idea of cultural citizenship suggests that placebased and trans-place forms of cultural difference and local and regional social movements are also a part of global transformations (see Dirlik 2000; Harcourt and Escobar 2002; Sahlins 1999). The reification of cultural difference has emerged in conjunction with the questioning of cultural and national borders in processes of globalization and migration. Thus, cultural citizenship suggests both recognition of cultural differences maintained through processes of migration and the opening up of the term citizen to embrace the contributions of all who live in communities in the United States.

The rest of this article uses the story of PCUN and worker testimonies to illustrate how cultural citizenship has been created for some farmworkers in the state of Oregon through grassroots organizing around immigration, cultural, and labor issues.

Notes on Methods and Collaborative Research Model

The research for this paper is driven by a model I call collaborative, activist ethnography, which draws on many elements found in applied anthropology, advocacy anthropology, and anthropology-in-practice that date to the 1980s. Books such as Collaborative Research and Social Change: Applied Anthropology in Action (Stull and Schensul 1987) and articles by Gwen Stem (1985) on "Research, Action, and Social Betterment"; Ronald Cohen (1985) on "Social Theory and Critical Analysis in Applied Anthropology"; and W. K. Barger and Ernesto Reza (1987) on "Community Action and Social Adaptation: The Farmworker Movement in the Midwest" discuss anthropological collaboration with communities, organizations, or groups in designing and carrying out their research. The goal of this type of research as outlined by Stull (1988:35) was to "make research and practice more responsive to local needs and interests.. and to enhance the capability of the community or population to use research as a tool for self-determination and development, to advocate on its behalf with outside agencies or institutions, and to 
develop its own research and practice capacities." In the 1980s these anthropologists collaborated in projects with Native American tribal governments (Stull 1988) and farmworker organizations in the Midwest (Barger and Reza 1987), state and city health departments and the Hispanic Health Council in Connecticut (Schensul et al. 1987), and organizations such as Community Action for Migrant Progress in Dade County, Florida (Cohen 1985). My research follows in this spirit.

The components of what I have called collaborative, activist anthropology include: 1. Collaboration: research topics, goals, methods, and outcomes are the result of a joint process between subjects and researchers-in this case jointly determined by PCUN staff, leadership, and me;

2. Activism: taking specific action for a particular sociopolitical process with which one is aligned and to which one feels accountable (see Hale 1997:836; Falla 1997); and

3. Ethnography: "the attempt to understand another life world using the self-as much of it as possible-as the instrument of knowing" and ... thickness,' i.e. producing understanding through richness, texture, and detail rather than parsimony, refinement, and (in the sense used by mathematicians) elegance" (Ortner 1995:173).

Together these three terms suggest ethnography produced through a collaborative process that is aligned with a clear sociopolitical process or goal. For the research discussed here, the goal was twofold: 1) documenting life histories of individual workers, the histories of movements in support of farmworkers, and the experiences, living and working conditions, and treatment of farmworkers; and 2) creating tools for educating the public to better guarantee the labor, human, and cultural rights of farmworkers-particularly those who are most vulnerable, the undocumented, and those from ethnic minorities within the farmworker population. The research was intended to make a contribution to validating the cultural citizenship of farmworkers in the U.S.

From 1998 to the present, I have been engaged in collaborative, activist ethnography with PCUN staff, organizers, and members, as well as with a team of graduate and undergraduate students from the University of Oregon. Students received academic credit for their involvement in the research. Our work has specifically involved conducting over 45 life-history interviews with Mexican migrants (primarily from the states of Oaxaca and Michoacan) about migration within Mexico; their ethnic origins and community life in Mexico; the stories of their journeys to the U.S.; their labor history in Mexico and in the U.S.; their participation in labor organizing; their home life; their thoughts on mainstream American society; their language and ethnic identity; and gender relations at 
home, work, and in any organizations to which they belong. We also carried out in-depth interviews with growers, contractors, union staff, and social service providers who work closely with farmworkers. We engaged in observation and conversations at labor camps, in the fields, in the homes of permanent farmworkers, at farmworker union headquarters, and at meetings of farmworkers. We also observed and interviewed laborers and managers at other sites where farmworkers are employed, including canneries, frozen food warehouses, frozen food processing plants, food services, and food preparation. One primary product of this research was a history of the organization titled "The Story of PCUN and the Farmworker Movement in Oregon" (Stephen 2001b). The history was used to educate PCUN's staff, volunteers, interns, the larger public, and as a fundraising tool with donors. Five hundred copies were published in the first run and distributed to libraries, public schools, and throughout the higher education system. In addition, copies were distributed to Latino advocacy organizations in Oregon and California. We also produced a bilingual timeline of the union's history that was mounted in the Union Hall and also functions as a traveling exhibit.

Another product of the research was a theatrical presentation called "The Life of a Strawberry." Students worked with me to carry out research, including interviews and participant observation in the fields, as well as in different sites in the chain of food production and processing, including canneries, frozen food processing plants, warehouses, distribution centers, and in university kitchens. During winter and spring terms, students wrote scripts gleaned from interviews with workers and rehearsed their presentations. "The Life of the Strawberry" was presented at a cultural night and rally at PCUN, at two academic conferences, at a student conference on farmworker organizing, for a junior high school class, and for a university class. A final product was a website (http:1l www.morsechair.uoregon.edu/strawberry.shtml).

The Denial of Full Citizenship to Mexican Immigrants and a Model for Reclaiming it: Cultural Citizenship

Since the 1920s, U.S. immigration policy in relation to Mexico has served primarily as a labor policy-inviting workers in when they are needed and then showing them the door when it becomes politically expedient to "defend" the border (see Carrasco 1997; Chavez 2001). While U.S. immigration policy has consistently "defended" the border from what are called illegal aliens, deeper historical analysis of particular policies, such as the Bracero Program from 1942-- 1964, the Immigration Reform and Control Act CIRCA) and the Special Agricultural Workers Program (SAW) of 1986, and a close examination 
of the accelerated integration of the U.S. and Mexican economies under economic neoliberalism and NAFTA suggest that U.S. immigration policy toward Mexico has in fact encouraged and facilitated increased immigration (see Massey 1997). In many ways, past U.S. immigration policy is directly responsible for the increased number of undocumented immigrants in Oregon and elsewhere in the country during the 1980s and 1990s (see Stephen 2001a).

Within the United States, Mexican immigrants may be documented or undocumented, but the historical construction of Mexicans in the U.S. as illegal aliens through the U.S. immigration policies outlined above denies them full citizenship, even if they are legally entitled to it. As stated by William V. Flores (1997a:255):

This country's anti-immigrant hysteria deflects our attention from a simple reality: being a citizen guarantees neither full membership in society nor equal rights. To be a full citizen one must be welcome and accepted as a full member of society with all of its rights. Unfortunately, full citizenship rights have systematically been denied to Latinos and to other nonwhite racial groups in the United States. In fact, even when Latinos are U.S.-born citizens, they have been treated as second-class or third-class citizens. While processes of immigration have certainly promoted the integration of the Americas through Latin American immigration to the United States, anti-immigrant cultural and political forces have pushed back at Latin American immigrants, often rendering them as "different" from the dominant society because of racial, cultural, and linguistic characteristics that mark them as "other" (Flores 1997a:256). John and Jean Comaroff (1992:60) and Stuart Hall (1988:2) have noted that socially constructed categories such as race and ethnicity are perceived as impassible symbolic boundaries that become fixed in nature and take on the appearance of an autonomous force capable of determining the course of social and economic life.

The label of "illegal" may be symbolically generalized to all Latin American immigrants, regardless of their technical, legal status. In Oregon, use of the label "illegal" for Latin American immigrants can be traced most recently to changes in how contracted workers were categorized while working under the Bracero Program and afterwards. 6 When they arrived in the state in 1943 and 1944, agricultural workers were written about as heroes in articles with headlines such as "Wheat Saved by Mexicans" (The Oregonian 1944) and "Mexican Harvesters Doing a Great Job in Fields and Orchards, Say Growers and Farmers Who Have Seen Them Work" (The Oregonian 1943). By the late 1940s and early 1950s these same workers were being called "wetbacks" and "illegals" in headlines 
such as "Agents Sweep Rising Tide of Mexican Illegals South to Border" (The Oregonian 1953).

While many of the farmworkers hired under the Bracero Program continued to be recruited by growers once the program ended, by the 1980s other national groups had joined the farmworker stream, including workers from Guatemala and El Salvador. Whether hailing from El Salvador, Guatemala, Peru, or Mexico, immigrants and citizens who now self-label as Latinos may find themselves being questioned by INS officials, police, or others who decide they "look illegal."

Renato Rosaldo (1997:31) describes this phenomenon:

A significant number of people in the United States, for example, have come to question the citizenship of Latinos by declaring undocumented workers to be "alien" or "illegal."

By a psychological and cultural mechanism of association all Latinos are thus declared to have a blemish that brands us with the stigma of being outside the law.

Rosaldo suggests that this stigma results in denial of full citizenship for Latinos who have citizenship rights and further marginalizes others such as legal residents and undocumented immigrants.

The experiences of PCUN members and other farmworkers I have interviewed bear out Rosaldo's ideas about being constantly perceived as "illegal." When farmworkers get to the point in their stories where they cross the border to the U.S. as undocumented people, the story takes on a different feeling as they describe the need to hide and the struggle to simply survive and work. The memories of the fear of being caught as a criminal without papers continue even if, and when, they do receive permission to legally reside in the United States.

Antonio Mendoza, now 52 years old, first came to the United States in 1978 from a small Mixtec community in Oaxaca. He left home at age 17 to work in Mexico City and then traveled northward to Ensenada, Mexico, close to the U.S. border. After working there for several months, he crossed over into California. He was robbed of his money and clothes during this first trip.

We sat at his kitchen table with his wife Angela, now 38, in the small, comfortable home in Salem, Oregon, they share with their three daughters and grandchild-a sharp contrast to what he was about to describe. Antonio received his legal residency in 1988 through the IRCA program. His wife, Angela, came to the United States in 1988 and received legal residency shortly thereafter as a result of her marriage to him. Both are members of PCUN. 
Antonio winced as he recalled his first time in the United States. "I paid a coyote $\$ 100$ there in Tijuana. I landed in Carlsbad and Oceanside. There were other people from my town there as well. Some of them went to San Quintin."7 Antonio then turned to me with a sad smile and said, "Then I started to make my house." He paused, looked at me, and continued:

but not the kind of house you think. I made my house below the ground. We dug way under, like this (pointing to the height of the table and even higher). We made it really deep. It was big enough so that 15 or 20 people could sleep there. We did this because we didn't want anyone to see us. We didn't want to get caught. We used a green tree branch for the door. We pulled it over the mouth of our house at night. That was how I started out in this country for the first time. A really hard life. We would leave in the morning to work in the fields and then come back at night to our house underground.

Antonio and Angela recalled what they felt like when they were both in the United States and had yet to get their legalization documents.

Lynn (to Angela and Antonio): What did it feel like when you first arrived?

Antonio: When I first arrived in 19791 was really glad. I came here and I thought I was going to start again. I decided not to smoke or drink. I said, "I am in a new place and why should I keep doing the same things in a new place?" So being here made me happy, on the one hand. On the other hand, when I was here without work and I had to pay for food and a place to live, it was really hard.... Later in 1988, I didn't have any papers. My boss wrote a letter for me to get amnesty (legal permission to work).

Angela: It is really hard for people. They are far away from their families. People never forget the fear they have when they don't have any papers.

Antonio: It is really important for people to know why I came. I came here with a good purpose in mind. I didn't come to cause problems. I just came to work ....That's all I came for.

Antonio and Angela have been living together in Salem, Oregon, for almost 15 years. They have both worked full time in a range of agricultural jobs. Angela has harvested strawberries and works in a nursery. Antonio planted trees for the U.S. Forest Service, harvested strawberries, and worked for 10 years in a mushroom plant. He was recently laid off from the mushroom plant when it closed and is part of a group of workers who received support from PCUN. Now he is employed in the same nursery as Angela. He took a 50 percent pay cut from his work in the mushroom factory when he began at the nursery. Through PCUN, family and community networks, and through a newly formed 
public works committee that remits money to their community in Oaxaca, Antonio and Angela are struggling to receive validation for their contributions to the economy, to the town of Salem, and to the U.S. in general. Their oldest daughter is about to graduate from high school and hopes to continue her studies in higher education.

Cultural citizenship provides a way to validate the contributions of Mexican immigrant workers such as Antonio and Angela. Cultural citizenship, as opposed to legal citizenship, can be "thought of as a broad range of activities of everyday life through which Latinos and other groups claim space in society and eventually claim rights" (Flores and Benmayor 1997:15). According to Flores and Benmayor (1997:11), the notion of cultural citizenship in a wider Latino society in the United States allows "immigrants who might not be citizens in the legal sense or who might not even be in the country legally, but who labor and contribute to the economic and cultural wealth of the country" to be "recognized as legitimate political subjects claiming rights for themselves and their children," and in that sense to be citizens. Thus citizenship-particularly locallybecomes predicated not on possession of certain immigration documents, but on concrete contributions to the community one lives in and the right to basic protections and respect. Cultural citizenship is also a useful concept for understanding how Oregon's only farmworker Union, PCUN, and the Willamette Valley Immigration Project (WVIP) that preceded it, have helped to create a sense of belonging for Mexican immigrant farmworkers in Marion County, Oregon. This has been achieved primarily through confronting regional cultural constructions of Mexican farmworkers as racial "others" and as marginalized social, political, and economic actors undeserving of basic labor rights and cultural recognition. The positive side to building a new sense of local citizenship and belonging involves the creation of alternative cultural and political spaces and organizations that affirm Mexican culture, identity, and immigrants' rights as workers and local residents.

Reclaiming Cultural Citizenship and Farmworkers' Rights in Oregon: Pineros y Campesinos Unidos del Nordoeste (PCUN)

In the early 1970s, several organizers inspired by the work of Cesar Chavez began to plan how they could build a social movement of Mexican immigrants and farmworkers in Oregon. Their vision was a broad one, incorporating community organizing, sponsorship of public cultural events linked to Mexican national heritage, legal defense of immigrants, creation of a broad coalition of support for the Mexican immigrant community, and of a strong, local organization that could represent the interests of 
Mexican immigrant workers in a variety of arenas-from local schools and housing to labor rights. Their initial organizing strategies were influenced by the climate of harassment and fear faced by Mexican immigrant farmworkers in the Willamette Valley. During the late 1960s and the early 1970s, there was a marked increase in INS activity targeting farmworkers, including raids in fields, on roads, in rental housing, and in labor camps. By 1973, INS deportations from Oregon were averaging about 1,000 per year (Kleinman n.d.). In October 1976, immigration raids at the Castle and Cook Mushroom Plant in Salem, Oregon, and in the city of Woodburn, Oregon, resulted in the deportation of 80 Mexican workers. In towns like Woodburn, where people of Mexican descent were beginning to form a significant minority, INS deportations and daily check-points and raids affected many people's daily lives. This climate stigmatized Mexican residents and rendered them marginal in community politics and decision making. The "illegal" label attached to some was extended to many.

In May 1977, the Willamette Valley Immigration Project (WVIP) opened its doors to provide legal representation for undocumented workers. In 1978 it moved from Portland to Woodburn, and in 1980, the WVIP purchased its own building. A special Cinco de Mayo (Fifth of May)-Primero de Mayo (International Workers' Day) celebration that year marked the move and the inauguration of the building. The WVIP also sponsored other cultural and political events, including bringing Teatro Primavera from Los Angeles to perform at the annual Fiesta Mexicana in Woodburn. In 1981, the project hosted a community meeting with Baldemar Velasquez, leader of the Farm Labor Organizing Committee (FLOC), which was based in the Midwest.

In the late 1970s, WVIP staff members established credibility with Mexican immigrants through their ongoing pressure on police and the INS to respect workers' legal rights. In October 1978, the organization made front page news when more than 100 workers were arrested in five days around Woodburn at the height of the cauliflower harvest. Larry Kleinman (not a pseudonym) recalls this and another important local victory that helped to build credibility:

[The raids] even included one couple who went to the local daycare center to pick up their infant.... We were able to talk the INS out of actually deporting those people because they had this U.S. citizen child.... The reason the INS backed out is because the press showed up... and the reason the press showed up is because we got them there.... That raid was so intense that Governor Straub ended up calling the INS to tell them to back off and they either were done or they backed off. I don't know which way it was, I 
think they were probably done anyway. But this [the advocacy of the WVIP] got noticed by everybody.... It got noticed in the community and got noticed in the media (Stephen interview, October 29, 1999). The cultural and political space that WVIP began in the 1970s continued with the formation of PCUN (Northwest Treeplanters and Farmworkers United) in 1985. The initial goal of PCUN was to change working conditions for treeplanters and farmworkers and to continue building a presence for Mexican immigrants in Woodburn and surrounding towns. The eight-year track record of the Willamette Valley Immigration Project was key to building trust in the Mexican immigrant community so that open discussion of a farmworker union could begin.

In December of 1985, Cesar Chavez visited Woodburn at the invitation of PCUN. He told PCUN members that economic pressure is the only message to which growers will listen, and farmworkers must "strike and boycott and create a lot of economic pressure on growers" (McManus 1985: 1). He also urged support for the reinstated grape boycott. "Farmers treat farmworkers like farm implements, rather than human beings," said Chavez. "If farmworkers don't get organized, farmworkers are going to continue to have the farmer's foot on our necks and we'll be fighting the same battle 100 years from now" (Castaneda 1985:1).

The cultural packaging of the union has relied on key figures and concepts built around the U.S.-based farmworker rights movement. This is most clearly represented in the figure of Cesar Chavez. Other cultural elements are most clearly linked to Mexican nationalism and to some degree to Chicano nationalism.

Since its inception, the union has celebrated Cinco de Mayo (commemorating the Battle of Puebla where Mexican forces put an end to French intervention in 1862) and International Workers' Day (A Mexican national holiday celebrated on May 1 to commemorate a general strike in 1886) in one celebration. In 1993, PCUN dedicated the annual event to the memory of Cesar Chavez, who died at the end of April. Such events often draw crowds of several hundred people and are well covered in local and regional newspapers.

During the 1990s, the union engaged in a series of actions aimed at opening up political and cultural space for immigrant Mexican farmworkers. Some of these actions concerned labor law violations. Because such actions involve defense of Mexican immigrant farmworkers, they need to be understood not only as "labor actions" but also as ethnic and cultural actions. For workers who benefit from such actions, they feel a sense of validation not only as workers, but also as Mexican immigrants. For some growers and 
others who may question the need for workers to assert their rights, such actions upset the cultural order of local power arrangements and begin to remake the place of "the illegals" in communities such as Woodburn. I highlight a few of these actions below with comments from organizers and participants to illustrate how they create a new sense of belonging and local, cultural citizenship for Mexican immigrant workers.

During the summer of 1990, PCUN activists conducted a "red card" wage campaign to help workers keep track of their earnings. Workers were given red cards to fill in with their daily earnings. Totals were kept and compared to pay stubs. PCUN organizers distributed over 10,000 time cards and were able to document 250 instances of workers receiving less than the minimum wage. PCUN filed wage claims with the Oregon Bureau of Labor and Industry for 40 workers who received more than $\$ 3,000$ collectively. PCUN was also able to force a labor contractor to pay back $\$ 9,000$ he had illegally withheld from farmworker paychecks through inflated charges for housing, food, and transportation. PCUN President Racoon Ramirez (not a pseudonym) recalls: We targeted five farmers..and Kraemer was the top one. All the workers would complain.... They came here all the way from Mount Angel, you know, just to complain about the Kraemers. I remember we talked to him that year. We said, "What's the deal man?"... The Kraemers had this labor contractor.... He would bring workers up here, most of the workers he brought were Mixteco. He would charge them for rides, for food.... He would feed them stuff like tacos de arroz [rice tacos]. And he would charge them $\$ 40$ per week for food, for tacos de arroz.... The Kraemers would give him a check and so what he was doing is that he would have a list of how much money you owe, then you'd sign your check and give it to him. He'd cash it for you and maybe give you back the difference of what you owe.... So that year, you know, we submitted over 100 wage claims to Kraemer. Then we won $\$ 9,000$. And we were able to develop this good relationship with probably about three or four crews of farmworkers (Stephen interview, October 15, 1999).

These concrete gains made a positive impression on people like Mariano Martinez, a farmworker from Michoacan who began to work with PCUN in the late 1980s. After receiving residency through the 1986 IRCA legislation, PCUN helped him bring the rest of his family to the United States.

I have seen through different experiences that they [PCUN] have helped a lot of the time and they have done a lot to help the community. I mean the farmworkers.... Here, the minimum wages were not rising and the growers just made us work.... They didn't pay 
hardly any salary at all, but they [PCUN] got involved and they asked about our salaries and they raised salaries for the entire community and asked that the growers respect us. Now they respect us more because of the work they did (Stephen interview, October 29, 1999).

These actions in 1990 helped create a climate where growers felt obligated to pay workers minimum wage, and contractors who supply workers to growers were held accountable for their treatment of workers. For farmworkers like Mariano, such change generated a sense of being respected for their work, which he told me was just as important as getting paid more.

Along with the 1990 wage actions, PCUN inaugurated a weekly one-hour radio show called La Hora Campesina (The Farmworker Hour). Broadcast on KWBY, the show's lively format encouraged farmworkers to call in and share information with each other. Long-time PCUN member Javier Ceja (not a pseudonym), who worked on the radio program, recalls how this open format eventually caused problems when the growers tuned in and pressured the broadcaster to shut it down.

People would call up and they would explain to me [on the air] everything that was going on. And then I would ask them more questions and we would keep talking. Sometimes people would name names... like who they worked for... like the so-and-so farm. They would talk about their living conditions, how much they were paid. They would talk about everything.... This is what caused us problems, like when they talked about the work conditions.... People would say that this grower didn't pay them well, that he paid them really cheap.... So maybe it was the contractors who heard it [the radio show] or people who understand Spanish and told the growers (Stephen interview, November 5, 1999).

After an extended battle with the broadcaster and a court battle, PCUN won the right to broadcast a few more segments and then moved the program to Portland, where it aired until June 1994. Nevertheless, a Spanish radio program oriented to Mexican farmworker issues and daily realities helped publicize the presence and concerns of the Mexican immigrant community in the region.

In 1995, PCUN developed a campaign to raise wages for strawberry workers using radio spots in Spanish, as well as Mixteco and Trique, indigenous languages of Oaxaca, Mexico. This strategy was key to reaching the increasing number of indigenous farmworkers in Oregon whose first language was not Spanish. PCUN activists began to deal more concretely with ethnic, linguistic, and cultural differences within the 
farmworker population. Not only did a discourse of rights have to be created for Mexican immigrant farmworkers, but it also had to recognize the ethnic variation within the farmworker population. This continues to be a challenge for PCUN because the composition of the farmworker labor force is increasingly indigenous. In building public understanding of and appreciation for Mexican immigrant workers, the union has to represent the diversity of that population. PCUN faces challenges in making its own cultural events and organizing strategies meaningful not only in terms of Mexican nationalism, but also to more recent Mexican indigenous immigrants whose ethnic and cultural distinctiveness has often been erased or ignored in portrayals of "Mexicanness." In the late 1990s, PCUN orchestrated Oregon's first collective bargaining between farmworkers and a grower-- Nature's Fountains Farms, a local organic grower. Agreements with three other growers were later signed. The agreements provided farmworkers with more than a dozen rights and protections not afforded by law, including seniority, grievance procedures, overtime, paid breaks, and union recognition. Sara Lopez was the leader of one of the negotiating teams that worked on the first PCUN contracts. She came to Oregon from her Mixtec community in Oaxaca, Mexico, in 1987, following her husband, who was legalized that same year. She worked for years in the berry fields of Oregon as well as in local canneries and frozen food processing plants. We discussed what the contracts meant to her in her living room in the fall of 2000. Lynn: What were the working conditions like when you had the contract? Were they different than before?

Sara: Of course they were not the same [with the contract]. We had clean bathrooms, we had fresh water to drink, we each had a glass with our own name on it for water. We got our break and we got to eat lunch. Before, we never got this. In the other places the bathrooms were filthy, they gave us warm water to drink, and we never even drank water, took breaks, or ate lunch because we had to keep picking in competition with others, or we wouldn't have enough work. In other places I worked, if you didn't get to the fields early and keep working in a big hurry, you wouldn't even earn enough money to pay for your food.... Under our contract they paid us the minimum and guaranteed us eight hours of work per day (Stephen interview, November 7, 2000).

In 2002, PCUN reached agreement on a framework for discussing collective bargaining with members of NORPAC Foods, a Northwest grower cooperative of 240 farms that PCUN had boycotted for 10 years. Discussions continued slowly throughout 2002 as PCUN organizers and NORPAC representatives worked to hammer out specific 
guidelines for election processes to be used by farmworkers as they consider union representation on 21 individual farms. This process has brought the union, Mexican farmworkers, Anglo growers, and the Woodburn area national attention.

In the 1990s, PCUN also had to respond to the increasing number of women migrating from Mexico to Oregon, often following husbands who had been legalized in the mid-1980s. Formed in 1997, Mujeres Luchadoras Progresistas (Women Fighting for Progress) provides a place for women who came from communities in Mexico where they seldom attended public meetings or expressed opinions outside of extended family gatherings. Begun as a women's income-- producing project, which each year sells hundreds of Christmas wreaths, the group also provides farmworker women with an opportunity to foster a sense of satisfaction, pride, mutual support, and to learn new skills in public speaking and leadership. The group provides a refuge for women, and they describe the meetings as having a "family feeling."

One participant in Mujeres Luchadoras Progresistas, Francisca Lopez, first came to the PCUN Service Center in 1997 to straighten out an auto insurance claim. She joined the group and eventually became very involved. She recalled how much the group means to the women who are socially isolated, lonely, and miss their extended families in Mexico. The kind of atmosphere created by a group of only women provides many who arrive with a special haven for sharing their feelings and working with others to resolve common issues. In their home communities in rural Mexico, men and women often lead quite separate lives. Women share problems and feelings with other women (usually relatives, neighbors, and close friends) at the market, while washing clothes, making tortillas, or during ritual events where men and women are segregated by gender. Men and women attend PCUN events together. Many women do not feel comfortable initially at these events and rarely speak in public or offer an opinion at union meetings. Attending meetings where only women are present can help to recreate some of the intimacy women left behind in their communities and give them the confidence to share their thoughts, concerns, and opinions. Once they have gained self-- confidence within the women's group, and practiced speaking in front of the group and leading discussions, they can translate these skills to other arenas, including union leadership, participation in local political forums such as PTA meetings and city council meetings, and renegotiation of domestic roles. The women's group is a safe, learning environment where members formulate opinions, practice public speaking, gain confidence in their opinions, and learn to share them in other public forums. As Francisca told me: 
A lot of women who come to the group have lived in poverty... they have families where the husband works but it isn't enough money to maintain the children and also to pay rent. We also have single mothers who arrive in the group who don't have anyone to help them. They come to the group and we help them. They come here and work and earn a little money.... And when they come here with us they begin to talk. It feels like coming to visit your family. When women come to be with us they feel comfortable and they begin to talk and it really helps. We can help women who want to talk about their problems.... It's different here. Women won't talk about things this way in a group of men. But this is a group of women, and they come and talk about their personal lives .... They talk about what they have done, what kind of suffering they are going through, and we help each other (Stephen interview, January 28, 2000).

Mujeres Progresistas became independent of PCUN in 2002. Union activists and the women in the group both viewed this as a success, an indication of the capacity of the women to be self-supporting and run their own organization.

During 1997, local PCUN members, staff, and allied organizations in Woodburn rallied residents to support naming one of two new public schools for Cesar Chavez, cofounder of the United Farmworkers (now called United Farmworkers of America) with Dolores Huerta. The Woodburn school board refused, instead naming the schools Heritage and Valor. The refusal prompted local residents to form the citizen's group, Voz Hispana (Hispanic Voice). Voz Hispana rallied more than 80 Latino residents to attend three consecutive school board meetings during the summer of 1997. Key participants in these meetings were 50 farmworker families who reside at the Nuevo Amanecer housing project built by PCUN's sister organization, Farmworker Housing Development Corporation. In these meetings, Voz Hispana pressured the school board to name the library at Valor Middle School for Chavez, to erect a permanent display about Chavez and his work, to declare his birthday (March 31) "Cesar Chavez Day" in all Woodburn schools, and demanded that special schoolwide and classroom activities be organized in celebration of that day. The Woodburn School Board agreed to all these requests. Since that time, special curricula and assemblies have been organized around Cesar Chavez that promote a sense of pride in the farmworker movement and provide a broader range of people with an education about the work and beliefs of this national hero. Voz Hispana continues to take an interest in local politics and has developed an interest in Latino voting and election participation in Woodburn.

Conclusions 
PCUN claims more than 4,500 people in and around Woodburn, Oregon, as members. Membership is defined as those who pay quarterly dues of $\$ 27$. Benefits include an insurance policy that pays $\$ 3,000$ in case of the death of a member, representation in immigration affairs, access to English and citizenship classes, and other resources. Beginning with issues of immigration abuses, detentions, and deportations, PCUN's work challenged the established racial, cultural, and political order in Woodburn and surrounding Marion County, where Mexican farmworkers were seen as illegal outsiders who did not have a voice at work, in the schools, or in the communities where they lived. The union and its predecessor, the Willamette Valley Immigration Project, have done crucial work over the past 25 years to secure labor rights, win contracts, change the terms of debate about conditions of employment in agriculture, defend the rights and needs of farmworker women and indigenous Mexican farmworkers, and achieve recognition for immigrant farmworkers as legitimate members of the communities where they live. The tools they have used to accomplish this have included grassroots organizing, leadership training, cultural events, radio broadcasts, and the creation of spin-off organizations such as Voz Hispana and the Farmworker Housing Development Corporation (an independent nonprofit organization cofounded by PCUN in 1990) that underwrote the building of 92 housing units for farmworkers in Woodburn. A combination of economic, political, and cultural strategies have led to an ever widening recognition of the economic and cultural contributions of Mexican immigrant farmworkers, respect for their rights at work and in the community, their incorporation into community political systems as participants and leaders, and recognition for key cultural heros for farmworkers such as Cesar Chavez. As William Flores (1997b:251) demonstrates in his analysis of the Watsonville Cannery Strike from 1985 to 1987, taking on cultural citizenship involves "agency and affirmation, reflecting on the active role of the oppressed in claiming what is their own, of defending it," and claiming an ever widening social sphere that reaches into their families, the plant, their union, and the city. As U.S. towns such as Woodburn, Oregon, undergo a demographic transition in which Latino immigrants become a significant minority and then a majority, the notion of cultural citizenship becomes increasingly important. It provides concrete alternatives to legal citizenship as the basis for granting recognition for the increasingly diverse population base of such communities and the rights to which those who live in them should be entitled.

The history of racial hierarchy associated with the formal terms used to define legal status in the United States is not easily discarded, and the color brown continues to be 
associated with "illegal alien" in the minds of many. Moving "citizenship" from the federal legal realm to the local realm and rooting it in the concrete contributions, obligations, and rights of people actually participating in communities returns the concept to the grassroots and empowers everyone to participate in defining it.

Cultural citizenship does not imply legal citizenship and is not intended to function as a legal category. It is a theoretical way to acknowledge the cultural, political, and economic contributions of legal residents and undocumented residents and remove the power of defining the social and cultural dimensions of citizenship from the U.S. government. While "cultural citizens" can still be deported if they are undocumented, if their contributions are valued and acknowledged at the local level then no one will have an interest in collaborating with agencies concerned with deportation. PCUN is unusual among unions in defending the rights of undocumented workers. While unions such as the AFL-CIO did not begin explicitly to support undocumented workers until the late 1990s, PCUN worked with undocumented workers since its founding as the Willamette Valley Immigration Project in 1977. Because of their historic defense of undocumented Mexican immigrants, sustained efforts to combat racism, discrimination, and unjust treatment of Mexican immigrant farmworkers, and ongoing struggles to construct new, positive forms of collective organization and public culture for Mexican immigrant workers, PCUN has helped build cultural citizenship for Mexican immigrants in Woodburn, Oregon, and well beyond.

My goals as an anthropologist and educator parallel some of the goals of PCUN in: 1) documenting the exploitation of Mexican immigrant farmworkers and how historical racism continues to marginalize many Latino workers in political, educational, and labor systems in the U.S; 2) highlighting the major contributions Mexican immigrants make to the U.S. economy and to the communities they live in; and 3) writing, teaching, and talking about how collective action by groups of Mexican immigrants can result in concrete positive changes in their working and living conditions. I am currently the only anthropologist researching and publishing about these issues in the state in Oregon. Through my research projects with students, publications, public speaking, and teaching, I am helping build public awareness about the challenges faced by recent Mexican immigrants and possible solutions, such as increases in the minimum wage, unionization, increased construction of farmworker housing, and recognition of cultural symbols of importance to Mexican immigrants in public education and community culture. I have provided PCUN with concrete tools, such as a history of their organization, an illustrated 
timeline, and a Web site that outlines worker conditions and relations of production from the fields all the way to the dinner plate.

According to the U.S. Census Bureau, there were 112,707 Spanish speakers in Oregon in 1990 (U.S. Census Bureau 1990). In 2000 that number jumped to 275,314, an increase of 144.4 percent. Of the 275,314 Spanish speakers reported in 2000, 214,662, or about 80 percent, were from Mexico (U.S. Census Bureau 2000). In 2000, Woodburn's population of 20,010 was slightly more than 50 percent Latino. Of the Latinos in Woodburn in 2000, 49.5 percent, or 8,945, were of Mexican origin (Woodburn City, Oregon, Statistics and Demographics 2000).

The Latino population is expected to double in Oregon in the next 10 years, reaching almost 20 percent of the total population. Producing a history of Mexican immigrant farmworkers and their movement in and outside of PCUN is of key importance in helping to educate the larger public. Oregon residents and students who are aware of the history and contributions of Mexican immigrant farmworkers are more likely to have respect for them and to understand their situation as they settle into communities, put their children in local schools, and begin to participate in churches, PTAs, community organizations, and other sites of civic and cultural interaction. Much more research is needed on the growing and ethnically diverse Mexican immigrant population in the state, and I look forward to working with other organizations and Latino community groups to provide information and tools that will contribute to the future well-being of Mexican immigrants in my state.

Notes

1Fransisco is a pseudonym. While "Fransisco" did give me permission to quote him, he left before I could ask whether he wanted me to use his real name. This pseudonym is used to protect his identity and status in the U.S. Unless otherwise stated, names used here are pseudonyms.

2The Bracero Program was created in an executive agreement between the U.S. and Mexican governments to alleviate labor shortages in the United States during World War II. Contract guarantees in terms of housing, transportation, wages, recruitment, health care, food, and the number of hours worked, were often not met. The program continued until 1964 and served as a major obstacle to farmworker organizing by labor unions. 3Mojado is often translated as "wetback," a reference to undocumented Mexicans who cross the Rio Grande River to enter the U.S. This racial slur was generalized to refer to all undocumented Mexicans and was standard vocabulary in past government documents 
and in the press.

4Latino refers to persons who live in the United States and trace their ancestry to Latin America or, in some cases, the Caribbean or Spain. The 2001 U.S. Census identified 35.8 million people as "Spanish/Hispanic/Latino." The term "Latino" was included for the first time in the 2000 census. In that census, people of Spanish/Hispanic/Latino origin could identify as Mexican, Puerto Rican, Cuban, or "other Spanish/ Hispanic/Latino." The Mexican American population, sometimes also referred to as "Chicano" (a more politicized term for people of Mexican origin linked to activist movements of Mexican Americans in the 1960s and 1970s), reached 20.6 million, or 7.3 percent of the total U.S. population of 281.4 million (See Guzman 2001:1-2).

5The number of farmworkers varies by source cited. PCUN organizers say there are approximately 100,000 farmworkers in Oregon. The 1997 Census of Agriculture puts the number at 124,4000, and the Oregon Employment Department puts the numbers between 40,100 and 86,400 in 1999, depending on the month. Many farmworkers who stay in the state for long periods work in the fields from June to September, then work in canneries, frozen food plants, restaurants, child care, and construction at other times of the year (see League of Women Voters of Oregon 2000; Stephen 2001 a).

6The Bracero Program in Oregon ended in 1947 when all labor camps were closed and contracted workers were supposed to return to Mexico. In other states, the program continued until 1964.

7Many people from Antonio's hometown have migrated to work in commercial agriculture in San Quint/n, Baja California. Others like Antonio began to cross over the U.S. border at that time into California in search of better wages (see Rivera Salgado 1999; Kearney 1995, Zabin and Hughes 1995).

\section{References Cited}

Appadurai, Arjun

1996 Modernity at Large: Cultural Dimensions of Globalization. Minneapolis: University of Minnesota Press.

Barger, W. K., and Ernesto Reza

1987 Community Action and Social Adaptation: The Farmworker Movement in the Midwest. In Collaborative Research and Social Change: Applied Anthropology in Action. Donald D. Stull and Jean J. Schensul, eds. Pp. 55-75. Boulder, Colo.: Westview Press.

Castaneda, Carol J. 
1985 Chavez in Woodburn to Urge Grape Boycott. The StatesmanJournal (Salem,

Oregon), December 4:A1.

Carrasco, Gilbert Paul

1997 Latinos in the United States: Invitation and Exile. In Immigrants Out! The New

Nativism and the Anti-Immigrant Impulse in the United States. Juan F. Perea, ed. Pp.

190-204. New York: New York University Press.

Chavez, Leo

2001 Covering Immigration: Popular Images and the Politics of the Nation. Berkeley:

University of California Press.

Cohen, Ronald

1985 Social Theory and Critical Analysis in Applied Anthropology. American

Behavioral Scientist 29:249-264.

Comaroff, John, and Jean Comaroff

1992 Ethnography and the Historical Imagination. Boulder, Colo.: Westview Press.

Dirlik, Arif

2000 Place-Based Imagination: Globalism and the Politics of Place. In Places and Politics

in an Age of Globalization. Rozann Praznick and Arif Dirlik, eds. Pp. 15-51. Lanham,

Md.: Rowan and Littlefield.

Falla, Ricardo

1997 Comment. Response to Consciousness, Violence, and the Politics of Memory in

Guatemala by Charles Hale. Current Anthropology 38:826-830.

Flores, William V.

1997a Immigrants and Latino Cultural Citizenship. In Latino Cultural Citizenship:

Claiming Identity, Space, and Rights. William V. Flores and Rina Benmayor, eds. Pp.

255-277. Boston: Beacon Press.

1997b Mujeres en Huelga: Cultural Citizenship and Gender Empowerment in a Cannery

Strike. In Latino Cultural Citizenship: Claiming Identity, Space, and Rights. William V.

Flores and Rina Benmayor, eds. Pp. 210-254. Boston: Beacon Press.

Flores, William V., and Rina Benmayor

1997 Introduction: Constructing Cultural Citizenship. In Latino Cultural Citizenship:

Claiming Identity, Space, and Rights. William V. Flores and Rina Benmayor, eds. Pp. 1-

23. Boston: Beacon Press.

Foley, Neil

1997 The White Scourge: Mexicans, Blacks and Poor Whites in Texas Cotton Culture. 
Berkeley: University of California Press.

Garcia, Matt

2001 A World of Its Own: Race, Labor, and Citrus in the Making of Greater Los

Angeles, 1900-1970. Chapel Hill: University of North Carolina Press.

Gutierrez, David

1995 Walls and Mirrors: Mexican americans, Mexican Immigrants, and the Politics of

Ethnicity. Berkeley: University of California Press.

Guzman, Betsy

2001 The Hispanic Population: Cencus 2000 Brief. Washington, D.C.: U.S. Cencus

Bureau.

Hale, Charles

1997 Consciousness, Violence, and the Politics of Memory in Guatemala. Current

Anthropology 38:817-824.

Hall, Suart

1988 New Ethnicities. In ICA Document 7:27-31. London: Institute for Community Arts (ICA).

Harcourt, Wendy, and Arturo Escobar

2002 Women and the Politics of Place. Development 45:7-13.

Hardt, Michael, and Antonio Negri

2000 Empire. Cambridge, Mass.: Harvard University Press.

Kearney, Michael

1995 The Effects of Transnational Culture, Economy, and Migration on Mixtec Identity

in Oaxacalifornia. In The Bubbling Cauldron: Race, Ethnicity, and the Urban Crisis.

Michael Peter Smith and Joe R. Feagin, eds. Pp. 226-243. Minneapolis: University of

Minneapolis Press.

Kleinman, Larry

n.d. Telling and Writing Our History. Unpublished manuscript. Woodburn, Ore.: PCUN Archives.

League of Women Voter of Oregon

2000 Farmworkers in Oregon. Report. Salem: League of Women Voters of Oregon

Education Fund.

Massey, Douglas

1997 March of Folly U.S. Imsuratn Policy After NAFTA. American Prospect 37:1-16. McManus, Kathy 
1985 Chavez Urges Workers to Fight for Rights. Woodburn Independent (Woodburn, Oregon), December 4:1.

Menchaca, Marta

2001 Recovering History, Constructing Race: The Indian, Black and White Roots of Mexican American Austin: University of Texas Press.

Oregonian, The

1943 Mexican Harvesters Doing a Great Job in Fields and Orchards, Say Growers and Farmers Who Have Seen Them Work. The Oregonian (Portland, Ore.), October 3: IA. 1944 Wheat Saved by Mexicans. The Oregonian (Portland, Ore.), October 11: IA. 1953 Agents Sweep Rising Ride of Mexican Illegals South to Border. The Oregonian (Portland, Ore.), May 15: IA.

Ortner, Sherry

1995 Resistance and the Problem of Ethnographic Refusal. Comparative Study of Society and History 37:173-193.

Rivera Salgado, Gaspar

1999 Welcome to Oaxacalifornia: Transnational Political Strategies Among Mexican Indigenous Migrants. Ph.D. thesis, Department of Sociology, University of California, Santa Cruz.

Rosaldo, Renato

1997 Cultural Citizenship, Inequality, and Multiculturalism. In Latino Cultural

Citizenship: Claiming Identity, Space, and Rights. William V. Flores and Rina

Benmayor. eds. Pp. 27-38. Boston: Beacon Press.

Rothenberg, Daniel

2000 With These Hands: The Hidden World of Migrant Farmworkers Today. Berkeley:

University of California Press.

Sahlins, Marshall

1999 What is Anthropological Enlightenment/Some Lessons of the Twentieth Century.

Annual Review of Anthropology 28. URL: (October 31, 2002).

Schensul, Jean J., Donna Henelli-Hess, Maria G. Borrero, and Ma Prem Bhavati

1987 Urban Comadronas: Maternal and Child Health Research and Policy Formulation in a Puerto Rican Community. In Collaborative Research and Social Change: Applied Anthropology in Action. Donald D. Stull and Jean J. Schensul, eds. Pp. 9-31. Boulder, Colo.: Westview Press.

Stephen, Lynn 
2001a Globalization, the State, and the Creation of Flexible Indigenous Workers: Mixtec Farmworkers in Oregon. Urban Anthropology and Studies of Cultural Systems and World Economic Development 30:189-214.

2001b The Story of PCUN and the Farmworkers Movement in Oregon. Eugene:

Department of Anthropology, University of Oregon.

Stem, Gwen

1985 Research, Action, and Social Betterment. American Behavioral Scientist 29:229248.

Stull, Donald D.

1988 Collaboration and Social Change. High Plains Applied Anthropologist 8(1):33-50.

Stull, Donald D., and Jean I Schensul, eds.

1987 Collaborative Research and Social Change: Applied Anthropology in Action.

Boulder, Colo.: Westview Press.

U.S. Census Bureau

1990 T-PIE. Age and Sex for the Hispanic Origin Population: 1990 Data Set: 1990

Summary Tape File 1 (STF I)100 Percent Data Geographic Area: Oregon. URL:

(December 18, 2002).

2000 Census 2000 PHC-T-10 Hispanic or Latino Origin for United States, Regions,

Divisions, States, and for Puerto Rico. Table I38 Hispanic or Latino Origin for Oregon:

2000. URL: (December 18, 2002).

Waslin, Michelle

2001 Immigration Policy in Flux. NACLA Report on the Americas 35(3):34-38.

Woodburn City, Oregon, Statistics and Demographics 2000

2000 Woodburn Population. URL: (December 18, 2002).

Zabin, Carol, and Sallie Hughes

1995 Economic Integration and Labor Flows: Stage Migration in Farm Labor Markets in Mexico and the United States. International Migration Review 29:395-422.

Dr. Stephen is professor and chair of the Department of Anthropology at University of Oregon. The author wishes to acknowledge the Wayne Morse Chair for Law and Politics at the Universit of Oregon for providing funding for the research described here. Undergraduate student researchers involved in the project included Mayra Gomez, Sarah Jacobson, Julie Meyers, Jill Nicola, Rachel Hansen, Gabriel Guzman, Jamie Shepherd, and Rosa Lopez. Graduate student researchers and assistants included Marcy Miranda Janes, Kristina Tiedje, Tami Hill, and Maria de la Torre. She also thanks the staff, 
leadership, and membership of PCUN and Margaret Hallock.

Copyright Society of Applied Anthropology Spring 2003_Provided by ProQuest Information and Learning Company. All rights Reserved 